\title{
Side \\ First report of papaya anthracnose caused by Colletotrichum salsolae in India
}

T.J. Saini ${ }^{1,2} *$ S.G. Gupta ${ }^{3}$ and R. Anandalakshmi ${ }^{2}$

${ }^{1}$ Department of Biotechnology, Government Institute of Science, Dr. Babasaheb Ambedkar Marathwada University, Aurangabad-431004, Maharashtra, India; ${ }^{2}$ Mahyco Research Centre, Dawalwadi, Jalna-431203, Maharashtra, India; ${ }^{3}$ Government Institute of Forensic Science, Nipatniranjan Nagar, Aurangabad-431004, Maharashtra, India

*E-mail: teju.saini@gmail.com

Received: 21 Feb 2017. Published: 15 May 2017. Keywords: Carica papaya

Papaya (Carica papaya) is an important fruit crop grown in tropical and subtropical regions of India. India ranks first in papaya production in the world with over 5.63 million tonnes produced annually (FAOSTAT, 2014). Anthracnose of papaya caused by Colletotrichum species is an important disease worldwide, resulting in post-harvest fruit decay which severely affects the marketability of the fruits (Ademe et al., 2014). In August 2016, papaya fruits showing typical anthracnose symptoms of small sunken spots were observed in two different fields in Badnapur, Jalna, Maharashtra, India (Fig. 1) and around 15\% of the papaya plants were affected.

The papaya fruits were semi ripe when harvested and ten fruits were incubated at $28^{\circ} \mathrm{C}$ in the dark for four-five days at $90 \%$ humidity to allow for further development of disease symptoms. Sunken necrotic fruit tissue was then examined under a microscope and conidia were inoculated onto potato dextrose agar (PDA) containing $50 \mathrm{mg} / \mathrm{l}$ streptomycin sulphate. The plates were incubated at $28^{\circ} \mathrm{C}$ with a $16 / 8 \mathrm{hr}$ light/dark cycle for five to seven days and pure cultures were obtained by sub-culturing onto fresh PDA plates. Identification of isolates was based on morphological as well as molecular characterisation. All ten fruits were found to be infected with Colletotrichum gloeosporioides and among them six fruits had a mixed infection of C. gloeosporioides and Colletotrichum salsolae. Only identification of the $C$. salsolae isolate is described here.

The putative $C$. salsolae isolate had white aerial mycelia with an olivecoloured colony and a light-salmon coloured conidial mass (Fig. 2). The mycelial growth rate on PDA at $28^{\circ} \mathrm{C}$ with $16 \mathrm{hr}$ photoperiod was $16 \mathrm{~mm}$ per day. Conidia obtained from incubated papaya fruits were single celled, cylindrical with a rounded base and apex. The mean length and width of conidia was $16.69 \pm 1.04 \mu \mathrm{m}$ and $5.56 \pm 0.18 \mu \mathrm{m}$, respectively (Fig. 3). The morphological characteristics of the isolate matched the description of $C$. salsolae (Weir et al., 2012). Molecular characterisation of the putative $C$. salsolae isolate involved PCR amplification of the partial $\beta$-tubulin gene using the universal primer pair Bt2a/b and GAPDH gene. Both sequences were deposited in GenBank (Accession Nos. KY401636 and KY401637 respectively) and aligned with published sequences using MEGA version 6.0 and phylogenetic analysis was done (Fig. 4). Blast searches in the NCBI database revealed that the $\beta$-tubulin and GAPDH gene sequences had $99 \%$ and 97\% identity to C. salsolae (KC790894 and JX009916, respectively).

The pathogenicity of $C$. salsolae isolated from infected papaya fruit was confirmed on healthy papaya fruits obtained from the local market. The fruits were washed with sterile distilled water and then surface sterilised with $70 \%$ ethanol for 30 seconds. Papaya fruits were wounded with a
Figure 1

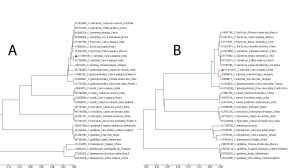

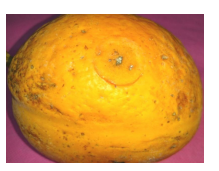

Figure 2
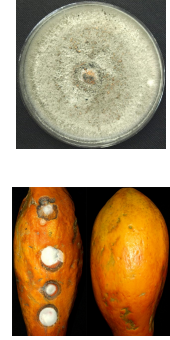

sterile syringe and inoculated with $10 \mu \mathrm{l}$ of a conidial suspension (c. $10^{5}$ conidia/ml). Sterile water was used as a control. Inoculated papaya fruits were kept in a chamber at $28^{\circ} \mathrm{C}$ in the dark with $90 \%$ humidity. After seven days typical anthracnose symptoms were observed on the inoculated papaya fruit but not on the controls (Fig. 5). Conidia were re-isolated from the inoculated symptomatic papaya fruits and characterised morphologically as well as molecularly and found to be identical to the original inoculated $C$. salsolae spores, thereby fulfilling Koch's postulates.

In India, Colletotrichum karstii (Sharma \& Shenoy, 2013), Colletotrichum fructicola and C. gloeosporioides (Saini et al., 2016) along with some other unverifiable records (Farr \& Rossman, 2017) have been reported to cause papaya anthracnose. To our knowledge, this is the first report of papaya anthracnose caused by $C$. salsolae in India. The pathogen has previously only been reported on Salsola tragus in Hungary (Weir et al., 2012). As this was a mixed infection it is not known what proportion of the affected fruits was infected by $C$. salsolae in the field. However, this new finding shows that $C$. salsolae is not host-specific and may occur in more geographical locations than is currently recorded.

\section{References}

Ademe A, Ayalew A, Woldetsadik K, 2014. In vitro and in vivo activity of selected plant extracts against papaya (Carica papaya L.) anthracnose (Colletotrichum gloeosporioides). Journal of Horticulture 1, 104. http://dx.doi.org/10.4172/2376-0354.1000104

FAOSTAT, 2014. FAOSTAT data collection. http://www.fao.org/faostat/en/\#data/QC (Accessed 20 April 2017).

Farr DF, Rossman AY, 2017. Fungal Databases, U.S. National Fungus Collections, ARS, USDA. https://nt.ars-grin.gov/fungaldatabases (Accessed 8 May 2017).

Saini TJ, Gupta SG, Anandalakshmi R, 2016. First report of papaya anthracnose caused by Colletotrichum fructicola in India. New Disease Reports 34, 27. http://dx.doi.org/10.5197/j.2044-0588.2016.034.027

Sharma G, Shenoy BD, 2013. Multigene sequence-based identification of Colletotrichum cymbidiicola, C. karstii and C. phyllanthi from India. Czech Mycology 65, 79-88.

Weir BS, Johnston PR, Damm U, 2012. The Colletotrichum gloeosporioides species complex. Studies in Mycology 73, 115-180.

http://dx.doi.org/10.3114/sim0011

To cite this report: Saini TJ, Gupta SG, Anandalakshmi R, 2017. First report of papaya anthracnose caused by Colletotrichum salsolae in India. New Disease Reports 35, 27. http://dx.doi.org/10.5197/j.2044-0588.2017.035.027 